\title{
Emerging mental health challenges, strategies, and opportunities in the context of the COVID-19 pandemic: Perspectives from South American decision-makers
}

\author{
Daniel A. Antiporta ${ }^{1}$ and Andrea Bruni ${ }^{2}$
}

Suggested citation Antiporta DA, Bruni A. Emerging mental health challenges, strategies, and opportunities in the context of the COVID-19 pandemic: perspectives from South American decision-makers. Rev Panam Salud Publica. 2020;44:e154. https://doi. org/10.26633/RPSP.2020.154

ABSTRACT Objective. To identify emerging mental health problems, strategies to address them, and opportunities to reform mental health systems during the COVID-19 pandemic in South America.

Methods. An online questionnaire was sent to mental health decision-makers of ministries of health in 10 South American countries in mid-April 2020. The semi-structured questionnaire had 12 questions clustered into three main sections: emerging challenges in mental health, current and potential strategies to face the pandemic, and key elements for mental health reform. We identified keywords and themes for each section through summative content analysis.

Results. Increasing mental health burden and needs were reported as direct and indirect consequences of the COVID-19 pandemic. National lockdowns challenge the delivery and access to mental health treatment and care. Strategies to meet mental health needs rely heavily on timely and adequate responses by strengthened mental health governance and systems, availability of services, virtual platforms, and appropriate capacity-building for service providers. Short- and medium-term strategies focused on bolstering community-based mental health networks and telemedicine for high-risk populations. Opportunities for long-term mental health reform entail strengthening legal frameworks, redistribution of financial resources, and collaboration with local and international partners.

Conclusions. Mental health and psychosocial support have been identified as a priority area by South American countries in the COVID-19 response. The pandemic has generated specific needs that require appropriate actions, including implementing virtual interventions, orienting capacity-building toward protecting users and health providers, strengthening evidence-driven decision-making, and integrating mental health and psychosocial support in high-level mechanisms guiding the response to COVID-19.

Keywords Mental health; coronavirus infections; South America.

Mental health and psychosocial problems are expected to rise during adversity and crisis (1), such as the COVID-19 pandemic (2), but awareness of mental health has already increased in the media and academic platforms (3). Isolation measures, discontinuity in health services, and scarce availability of medications represent additional barriers to preserving good mental health

\footnotetext{
1 Johns Hopkins Bloomberg School of Public Health, Baltimore M.D., United States of America
}

during the pandemic. While the Inter-Agency Standing Committee (IASC) (4) has provided guidance for mental health and psychosocial support (MHPSS) at a global level, evidence to guide action at regional and subregional levels is still insufficient. Regional and country-based research can help reduce the evidence-gap on local mental health action and strategies.

\footnotetext{
2 Pan American Health Organization/World Health Organization, Lima, Peru $\square$ Andrea Bruni bruniand@paho.org
} 
Historically, mental health care has been severely under-resourced (5); however, some regions, like South America, have made substantial progress regarding national policies and legal frameworks. For instance, Peru initiated a radical mental health reform in 2015, shifting from hospital-centered mental health toward a community-based model (6). While many South American countries are fiercely fighting the spread of the virus, additional challenges-for example, increased mental health needs-have arisen amid this pandemic. Key responses in mental health entail a deeper understanding of local needs and interventions as well as identification of opportunities to strengthen mental health care.

We aim to portray the subregional situation in mental health challenges during the early stage of the pandemic in South America. We gathered information from decision-makers on the main mental health needs, emerging challenges, and strategies to reduce the negative impact of the pandemic.

\section{MATERIALS AND METHODS}

We identified mental health focal points in ministries of health in all countries that belong to the Pan American Health Organization (PAHO) South America subregion: Argentina, Bolivia, Brazil, Chile, Colombia, Ecuador, Paraguay, Peru, Uruguay, and Venezuela. Electronic invitations were sent by email to at least one focal point per country during 10-15 April 2020.

An online semi-structured questionnaire (Table 1) was designed using Qualtrics (Provo, UT) and included nine country-specific questions, divided into three sections: 1) emerging challenges in mental health; 2) current and potential strategies (short-term, next two months; and medium-term, next six months) to face the pandemic; and, 3) strategies and opportunities for mental health reform. A qualitative approach was used, performing summative content and thematic analysis. We used the software ATLAS.ti 8 for Windows to facilitate data management and organization.

We used the terms lockdown, quarantine, and stay-at-home policies interchangeably, considering the local context and the purposes of the study. Using stress reactions, we intended to capture all mental and psychosocial conditions and reactions that require "any type of support that aims to protect or promote psychosocial well-being and/or prevent or treat mental disorder" (7). This included keywords such as stress, post-traumatic stress, acute stress, and severe stress. Lastly, we used anxiety to describe terms such as anxiety disorders and anguish.

The protocol and questionnaire were submitted to the Johns Hopkins Bloomberg School of Public Health and the PAHO ethics review committee, and all procedures were exempted from review.

\section{RESULTS}

We received nine out of 10 completed questionnaires, representing nine countries, and $44 \%$ of respondents were female. All respondents held high-rank decision-making positions in mental health units, programs, or departments in the ministry of health of their respective countries.

\section{Emerging mental health problems and psychosocial reactions}

Informants reported up to 12 different emerging problems across countries. The most frequent reactions reported were anxiety, stress, and fear. Reactions were attributed to the pandemic itself and to the public health measures that countries implemented to control the disease, such as total lockdowns and stay-at-home policies. Another common topic was domestic violence affecting children and women. Less frequent problems included insomnia, irritability, solitude, and sadness, especially among those living alone. Informants ranked anxiety or anxiety disorders top, based on the urgency to intervene, although a few also indicated stress reactions and fear.

\section{Challenges for mental health services delivery}

Participants indicated several challenges for mental health care delivery arising during the COVID-19 pandemic, for which the identification of high-risk populations is key to planning appropriate responses. Prioritized target populations include service providers, patients who were already in contact with

TABLE 1. Semi-structured questionnaire for directors/staff of mental health units

\begin{tabular}{|c|c|}
\hline 1 & Emerging mental health challenges during the COVID-19 epidemic \\
\hline 1.1 & What are the main mental health conditions and psychosocial reactions emerging during the outbreak? \\
\hline 1.1 .1 & Could you rank the top 3 by priority (starting by the top 1)? \\
\hline 1.2 & What are the main challenges emerging during the outbreak in terms of delivery of mental health services? \\
\hline 1.2 .1 & Could you rank the top 3 by priority (starting by the top 1)? \\
\hline 1.3 & What are the main challenges emerging during the outbreak in terms of access of mental health services? \\
\hline 1.3 .1 & Could you rank the top 3 by priority (starting by the top 1)? \\
\hline 2 & Potential and current strategies to reduce the negative impact of the epidemic on mental health and well-being \\
\hline 2.1 & What key strategies are being implemented to specifically address the mental health and well-being needs affected by the epidemic? \\
\hline 2.2 & What innovative actions and interventions would you consider for implementation in the short-term response? \\
\hline 2.3 & What innovative actions and interventions would you consider for implementation in the medium-term response? \\
\hline 3 & $\begin{array}{l}\text { Key elements to reform mental health systems and services, seizing opportunities during the crisis. Despite their tragic nature, and notwithstanding the } \\
\text { human suffering they create, emergency situations are also opportunities to build better mental health care. }\end{array}$ \\
\hline 3.1 & What strategies should be adopted to prioritize mental health in the political agenda? \\
\hline 3.2 & What opportunities have you identified to mobilize additional financial resources? \\
\hline 3.3 & Who are the international partners that you identify to support and strengthen mental health services? \\
\hline
\end{tabular}


the mental health services, and potential new users that might need mental health support as a result of the pandemic, including those people that lost a relative or a loved one.

Challenges that referred to the services offered were grouped into outpatient services, inpatient care, and availability of medications. Outpatient services challenges included the limited capacity of health services to use virtual/telemedicine platforms to provide care to specific populations-i.e., older adults and indigenous communities_or disseminate key messages and relevant information through mass media. Challenges for inpatient care concerned adequate time for admissions and care provided during the lockdown. Disruption in the availability of psychotropic medications was described in terms of reduced access and distribution to inpatient and outpatient care facilities. Additional challenges were the limited availability of virtual platforms and limited time for training service providers on adequate responses in mental health care, such as psychological first aid.

\section{Challenges for mental health services access}

The main reported barriers for accessing mental health services, including therapies and other types of care, were the national lockdown measures, which shut down most primary health centers to stop the spread of the disease. Scarce resources to reorganize mental health services to virtual forms and systems for appointments were also described as challenges that jeopardize access to services. The delivery of virtual treatments and interventions relies on the availability of services as well as the patient's expertise to use technological tools, which are not optimal during the current scenario. Access to medications was also reported as a potential challenge, given the lower availability of psychotropic medications compared with those used in general health and for conditions related to COVID-19.

\section{Strategies to face the needs in mental health during the pandemic}

Strategies that have been implemented frequently during this pandemic include mass communication media at the national and local levels. Communication strategies for psychosocial education and support considering cultural and gender perspectives were also suggested. An example of the latter is the digital system of mental health care for health providers in Chile. Other strategies included establishing or strengthening mental health services through telemedicine and national or local hotlines for mental health care and psychosocial support. Access to pharmacological treatment was also a concern; solutions that participants proposed to bridge the gap included the establishment of a virtual delivery system and partnerships with existing pharmaceutical networks to facilitate access to these treatments.

For the medium term, the creation and use of virtual platforms and applications for delivery of mental health services, strengthening of social networks, and offering psychosocial support were all considered highly relevant. A mobile application in Colombia that aims to screen for COVID-19 symptoms was cited as an example of an app that can provide mental health care information to a broader population. A recurrent topic among respondents was the need for a community-based mental health system, which strengthens the capacities of non-specialized primary health providers.

\section{Opportunities for mental health reform}

Participants suggested the creation and inclusion of commissions for mental health within technical working groups, which would allow mental health services to be prioritized not only in the current response but also in the post-pandemic setting. Partnerships with local organizations and civil society were also proposed as crucial to enhance the mental health response during the crisis. Some participants suggested that reorienting mental health services toward a community-based system would provide appropriate care tailored to the needs of the population. Lastly, building information systems using timely and robust data will allow the monitoring of mental health burden and associated factors, to better inform stakeholders.

When asked about opportunities to mobilize additional financial resources for mental health, some respondents suggested redirecting resources from more specialized facilities toward the primary health networks or community-based centers. Effective collaborations with local and regional authorities might facilitate the implementation of current mental health policies and lead to the allocation of additional funds. International partners, such as cooperation bodies, were considered as potential sources of financial support and collaboration for articulated efforts in mental health care during the pandemic. The most cited organizations were PAHO/World Health Organization and UNICEF.

\section{DISCUSSION}

An emerging burden of mental health needs is arising as direct and indirect consequences of the pandemic among the general population and health care providers in South America. National lockdowns and social distancing measures challenge the access to and delivery of mental health care and treatment. Strategies to meet these health needs heavily rely on timely and adequate responses by strengthened mental health governance and systems, availability of services, virtual platforms, and appropriate capacity-building for service providers. Shortand medium-term strategies focus on the implementation of community-based mental health systems, virtual support, communications, and proper care for populations in vulnerable or high-risk settings. Opportunities for long-term mental health reform entail strengthening legal frameworks, redistribution of financial resources, and collaboration with local and international partners.

Emergency situations usually result in a higher prevalence of mental conditions, including stress reactions and common and severe mental disorders $(1,8)$. Participants reported a higher burden of anxiety and stress in their respective countries. Detrimental effects on mental health have been reported in the general population $(9,10)$ and health providers (11-13) and overburden health services (14). Moreover, the more confined living conditions resulting from lockdowns and stayat-home policies may result in increased tensions $(15,16)$ and violence (2), including violence against women and children. People with mental health disorders and disabilities may suffer more disruption in services and accommodation than before COVID-19 (17).

Participants emphasized the relevance of ensuring the continuity of services. The capacity to adjust to the increased volume of people in need largely depends on the existing mental health 
infrastructure. Health systems centered on acute care hospitals and psychiatric hospitals may struggle to respond to the increasing needs of the population, and the preexisting mental health treatment gap may widen. Therefore, community-based mental health centers represent an invaluable resource at the heart of mental health community networks to respond to the needs of the population.

Another important theme that emerged was the need for expanding mental health services through telemedicine initiatives. Successful examples of these interventions have been shown in China, where surveys, mental health education, and psychological counseling services were implemented through online services (18). In Colombia, a smartphone application was launched to provide support to COVID-19-affected populations, which includes a component entirely dedicated to mental health to orient users and provide them with appropriate information (19).

A situation of crisis, such as the COVID-19 pandemic, despite its inherent, dramatic, disruptive consequences, may generate important opportunities for improving mental health services (20). The increased awareness of mental health by stakeholders, the media, and the general population represents an opportunity to increase the visibility of mental health, to mobilize resources, and to prioritize mental health policies and interventions. All respondents in our study provided insights on seizing potential opportunities to reform mental health services from a long-term perspective.

This study sought the expert opinions of decision-makers in high-rank positions in mental health units in ministries of health in South America, who were instrumental in identifying specific strategies to operationalize recommendations. However, the authors acknowledge the need to generate additional evidence and further investigate the perspectives of other key actors, including senior mental health professionals such as psychiatrists and psychiatric nurses, as well as representatives from civil society such as service users and their family members or caregivers. We gathered information from all countries except Brazil-the biggest country in the subregion and the one most affected by the COVID-19 pandemic-due to administration changes during the data collection period. Nevertheless, we aimed to portray the subregional situation regarding mental health challenges and not country-specific profiles. Collecting information from decision-makers from nine out of 10 countries allowed us to fulfill that objective.

Mental health and psychosocial support have been identified as a priority area by South American countries in the COVID-19 response. The pandemic has generated specific needs that require appropriate actions, including implementing virtual interventions, orienting capacity-building toward protecting users and health providers, strengthening evidence-driven decision-making, and integrating mental health and psychosocial support in high-level mechanisms guiding the response to COVID-19.

Author contributions. AB conceived the research idea. DA developed the research protocol. $\mathrm{AB}$ and $\mathrm{DA}$ developed the questionnaire. DA analyzed the data. DA and AB contributed equally to the discussion and conclusions. Both authors reviewed and approved the final version.

Acknowledgments. The authors acknowledge the participants of this study, their willingness to contribute to our research, and the mental health responses they are leading in their countries.

\section{Conflicts of interest. None declared.}

Disclaimer. Authors hold sole responsibility for the views expressed in the manuscript, which may not necessarily reflect the opinion or policy of the RPSP/PAJPH and/or PAHO.

\section{REFERENCES}

1. World Health Organization; United Nations High Commissioner for Refugees. Assessing mental health and psychosocial needs and resources: toolkit for humanitarian settings. Geneva: WHO; 2012. Available from: https://www.who.int/mental_health/resources/ toolkit_mh_emergencies/en/.

2. Galea S, Merchant RM, Lurie N. The mental health consequences of COVID-19 and physical distancing: the need for prevention and early intervention. JAMA Intern Med. 2020;180(6):817-8. https:// doi.org/10.1001/jamainternmed.2020.1562

3. Mental health and COVID-19: change the conversation. Lancet Psychiatry. 2020;7(6):463. https://doi.org/10.1016/S2215-0366(20) 30194-2

4. Inter-Agency Standing Committee Reference Group on Mental Health and Psychosocial Support in Emergency Settings. Interim briefing note: addressing mental health and psychosocial aspects of COVID-19 outbreak, version 1.5. Geneva: IASC; 2020 February. Available from: https://interagencystandingcommittee.org/iascreference-group-mental-health-and-psychosocial-support-emergencysettings/interim-briefing

5. Wainberg ML, Scorza P, Shultz JM, Helpman L, Mootz JJ, Johnson $\mathrm{KA}$, et al. Challenges and opportunities in global mental health: a research-to-practice perspective. Curr Psychiatry Rep. 2017;19:28. https://doi.org/10.1007/s11920-017-0780-z

6. Toyama M, Castillo H, Galea JT, Brandt LR, Mendoza M, Herrera $\mathrm{V}$, et al. Peruvian mental health reform: a framework for scaling-up mental health services. Int J Health Policy Manag. 2017;6(9):501-8. https://doi.org/10.15171/ijhpm.2017.07

7. Inter-Agency Standing Committee. IASC guidelines on mental health and psychosocial support in emergency settings. Geneva: IASC; 2007. Available from: https://www.who.int/mental_health/ emergencies/9781424334445/en/.

8. Ventevogel P, van Ommeren M, Schilperoord M, Saxena S. Improving mental health care in humanitarian emergencies. Bull World Health Organ. 2015;93:666-666A. https://doi.org/10.2471/BLT.15.156919

9. Ozamiz-Etxebarria N, Dosil-Santamaria M, Picaza-Gorrochategui M, Idoiaga-Mondragon N. Stress, anxiety, and depression levels in the initial stage of the COVID-19 outbreak in a population sample in the northern Spain. Cad Saúde Pública. 2020;36(4):e00054020. https:/ / doi.org/10.1590/0102-311X00054020

10. Rajkumar RP. COVID-19 and mental health: a review of the existing literature. Asian J Psychiatr. 2020;52:102066. https:/ /doi.org/10.1016 /j.ajp.2020.102066

11. Rossi R, Socci V, Pacitti F, Di Lorenzo G, Di Marco A, Siracusano A, et al. Mental health outcomes among frontline and second-line health care workers during the coronavirus disease 2019 (COVID-19) pandemic in Italy. JAMA Netw Open. 2020;3(5):e2010185. https:/ / doi. org/10.1001/jamanetworkopen.2020.10185

12. Abbasi J. Prioritizing physician mental health as COVID-19 marches on. JAMA. 2020;323(22):2235-6. https://doi.org/10.1001/ jama.2020.5205 
13. Chen Q, Liang M, Li Y, Guo J, Fei D, Wang L, et al. Mental health care for medical staff in China during the COVID-19 outbreak. Lancet Psychiatry. 2020;7(4):e15-e16. https://doi.org/10.1016/ S2215-0366(20)30078-X

14. de Girolamo G, Cerveri G, Clerici M, Monzani E, Spinogatti F, Starace F, et al. Mental health in the coronavirus disease 2019 emergency-the Italian response. JAMA Psychiatry. 2020;77(9):9746. https://doi.org/10.1001/jamapsychiatry.2020.1276

15. Mezzina R, Sashidharan SP, Rosen A, Killaspy H, Saraceno B. Mental health at the age of coronavirus: time for change. Soc Psychiatry Psychiatr Epidemiol. 2020;55:965-8. https://doi.org/10.1007/ s00127-020-01886-w

16. Brooks SK, Webster RK, Smith LE, Woodland L, Wessely S, Greenberg $\mathrm{N}$, et al. The psychological impact of quarantine and how to reduce it: rapid review of the evidence. Lancet. 2020;395(10227): 912-20. https:// doi.org/10.1016/S0140-6736(20)30460-8

17. Yao H, Chen J-H, Xu Y-F. Patients with mental health disorders in the COVID-19 epidemic. Lancet Psychiatry. 2020;7(4):e21. https:// doi.org/10.1016/S2215-0366(20)30090-0
18. Liu S, Yang L, Zhang C, Xiang Y-T, Liu Z, Hu S, et al. Online mental health services in China during the COVID-19 outbreak. Lancet Psychiatry. 2020;7(4):e17-e18. https://doi.org/10.1016/ S2215-0366(20)30077-8

19. Government of Colombia [Internet]. CoronApp. Available from: https: / / coronaviruscolombia.gov.co/Covid19/aislamientosaludable/coronapp.html (accessed 2020 June 1).

20. World Health Organization. Building back better: sustainable mental health care after emergencies. Geneva: WHO; 2013. Available from: https://www.who.int/mental_health/emergencies/ building_back_better/en/.

Manuscript received on 22 June 2020. Revised version accepted for publication on 8 September 2020.

\section{Desafíos, estrategias y oportunidades emergentes para la salud mental en el contexto de la pandemia de COVID-19: Perspectivas de los encargados de tomar decisiones en América del Sur}

RESUMEN

Palabras clave
Objetivo. Determinar los problemas de salud mental emergentes, las estrategias para abordarlos y las oportunidades para reformar los sistemas de salud durante la pandemia de COVID-19 en América del Sur.

Métodos. A mediados de abril del 2020, se envió un cuestionario en línea a los encargados de tomar decisiones en materia de salud mental en los Ministerios de Salud de diez países de América del Sur. El cuestionario semiestructurado consistía en doce preguntas agrupadas en tres secciones principales: desafíos emergentes en materia de salud mental, estrategias actuales y posibles para enfrentar la pandemia, y elementos clave para la reforma de la salud mental. Establecimos palabras clave y temas para cada sección mediante el análisis del contenido sumativo.

Resultados. Se informó un aumento de la carga y las necesidades en materia de salud mental como consecuencia directa e indirecta de la pandemia de COVID-19. Los confinamientos a nivel nacional representan un desafío en la prestación y el acceso al tratamiento y la atención de la salud mental. Las estrategias para satisfacer las necesidades de salud mental dependen en gran medida de las respuestas oportunas y adecuadas, que requieren el fortalecimiento de la gobernanza y de los sistemas en el ámbito de la salud mental, la disponibilidad de servicios y plataformas virtuales, y la formación de capacidad apropiada para los prestadores de servicios. Las estrategias a corto y mediano plazo se centran en reforzar las redes comunitarias de salud mental y la telemedicina para los grupos poblacionales de alto riesgo. Las oportunidades para la reforma de la salud mental a largo plazo entrañan fortalecer los marcos jurídicos, la redistribución de los recursos financieros y la colaboración con los asociados a nivel nacional e internacional.

Conclusiones. En los países de América del Sur, se ha determinado que la salud mental y el apoyo psicosocial son un área prioritaria en la respuesta a la COVID-19. La pandemia ha generado necesidades específicas que requieren medidas apropiadas, como las intervenciones virtuales, la orientación de la formación de capacidad hacia la protección de los usuarios y prestadores de servicios de salud, el fortalecimiento de la toma de decisiones basadas en la evidencia, y la integración de la salud mental y el apoyo psicosocial en los mecanismos de alto nivel que guían la respuesta a la COVID-19.

\section{Salud mental; infecciones por coronavirus; América del Sur.}




\section{Desafios, estratégias e oportunidades emergentes em saúde mental no contexto da pandemia de COVID-19: as perspectivas dos decisores sul-americanos}

RESUMO Objetivo. Identificar problemas emergentes de saúde mental, as estratégias para enfrentá-los e oportunidades para reformar os sistemas de saúde mental durante a pandemia de COVID-19 na América do Sul.

Métodos. Em meados de abril de 2020, enviamos um questionário online aos responsáveis pela tomada de decisões em saúde mental dos ministérios da saúde de 10 países da América do Sul. O questionário semiestruturado continha 12 perguntas agrupadas em três seções principais: desafios emergentes em saúde mental, estratégias atuais e potenciais para enfrentar a pandemia e elementos-chave para a reforma da saúde mental. Identificamos palavras-chave e temas para cada seção através da análise de conteúdo sumativa.

Resultados. O aumento das necessidades e da carga sobre os serviços de saúde mental foram descritos como consequências diretas e indiretas da pandemia de COVID-19. As medidas de confinamento implementadas pelos governos nacionais dificultam o acesso e a prestação de cuidados e tratamentos de saúde mental. As estratégias para atender às necessidades de saúde mental dependem de respostas rápidas e adequadas através do fortalecimento da governança e dos sistemas de saúde mental, da disponibilidade de serviços, de plataformas virtuais e da capacitação apropriada dos prestadores de serviços. As estratégias de curto e médio prazo se concentraram no reforço das redes comunitárias de saúde mental e da telemedicina para as populações de alto risco. As oportunidades de reforma da saúde mental a longo prazo implicam o fortalecimento dos quadros jurídicos, a redistribuição de recursos financeiros e a colaboração com parceiros locais e internacionais.

Conclusões. A saúde mental e o apoio psicossocial foram identificados como uma área prioritária pelos países da América do Sul na resposta à COVID-19. A pandemia criou necessidades específicas que exigem ações apropriadas, incluindo a implementação de intervenções virtuais, a capacitação orientada à proteção dos usuários e prestadores da atenção à saúde, o fortalecimento da tomada de decisões baseada em evidências e a integração da saúde mental e do apoio psicossocial em mecanismos de alto nível que orientem a resposta à COVID-19.

Palavras-chave Saúde mental; infecções por coronavirus; América do Sul. 